\title{
Efficacy of $\mathrm{Ag}-\mathrm{CuO}$ Filler Tape for the Reactive Air Brazing of Ceramic-Metal Joints
}

\author{
Myung Dong Kim*, Wahid Muhamad FR*, Kati Raju***, Seyoung Kim**;, \\ Ji Haeng Yu**, Chun Dong Park**, and Dang-Hyok Yoon**; \\ *School of Materials Science and Engineering, Yeungnam University, Gyeongsan 38541, Korea \\ **Energy Efficiency and Materials Research Division, Korea Institute of Energy Research, Daejeon 34129, Korea
}

(Received June 12, 2018; Revised July 4, 2018; Accepted July 19, 2018)

\begin{abstract}
This paper reports the efficacy of tape casting using an Ag-10 wt\% CuO filler for the successful joining of a sintered $\mathrm{Ce}_{0.9} \mathrm{Gd}_{0.1} \mathrm{O}_{2-\delta}-\mathrm{La}_{0.7} \mathrm{Sr}_{0.3} \mathrm{MnO}_{3 \pm \delta}$ (GDC-LSM) ceramic with a SUS $460 \mathrm{FC}$ metal alloy by reactive air brazing. The as-prepared green tape was highly flexible without drying cracks, and the handling was easy when used as a filler material for reactive air brazing. Heat treatment for the GDC-LSM/SUS $460 \mathrm{FC}$ joint was performed at $1050^{\circ} \mathrm{C}$ for 30 min in air. Microstructural observations indicated a reliable and compact joining. The room temperature mechanical shear strength of the as-brazed joints was $60 \pm 8$ $\mathrm{MPa}$ with a cohesive failure. The flexural strength of joints was measured from room temperature up to $850^{\circ} \mathrm{C}$, where the strength retention revealed to be almost $100 \%$ at $500^{\circ} \mathrm{C}$. However, the joints showed a degradation in strengths at 800 and $850^{\circ} \mathrm{C}$, exhibiting strength retentions of $57 \%$ and $37 \%$, respectively.
\end{abstract}

Key words : Tape casting, Reactive air brazing, Joining, Microstructure, Shear strength

\section{Introduction}

$\mathrm{C}$ $\mathrm{e}_{0.9} \mathrm{Gd}_{0.1} \mathrm{O}_{2-\delta}-\mathrm{La}_{0.7} \mathrm{Sr}_{0.3} \mathrm{MnO}_{3 \pm \delta}(\mathrm{GDC}-\mathrm{LSM})$ ceramic is one $\mathcal{U}_{\text {of the most promising materials for oxygen separation }}$ among dual-phase ceramic oxygen transport membranes (OTMs), owing to its relatively high oxygen permeation flux and structural stability. ${ }^{1,2)}$ From a theoretical point of view, OTM membranes should be as thin as possible to maximize the oxygen flux through the membranes. ${ }^{3,4)}$ Therefore, a multilayered structure has been suggested, where the sealing/joining of ceramic membranes is essential. Moreover, the ceramic-to-metal joining is also needed because thin ceramic membranes need to be supported by metal supports with high joining strength. Therefore, the sealing/joining of OTMs with reliable microstructures, strengths, and in-service integrity has been the subject of substantial research over the last few years. ${ }^{5-7)}$

Reactive air brazing (RAB) is used widely to join ceramicto-ceramic and ceramic-to-metal parts because of its simplicity, reliability, and cost effectiveness. ${ }^{8-16)}$ The Ag-CuO system is considered a suitable brazing material for RAB because of its good wetting behavior on both ceramic and metal in air. ${ }^{7,12)}$ Room temperature high strengths with a

\footnotetext{
${ }^{\dagger}$ Corresponding author: Dang-Hyok Yoon

E-mail : dhyoon@ynu.ac.kr

Tel : +82-53-810-2561 Fax : +82-53-810-4628

${ }^{\text {tC}}$ Corresponding author : Kati Raju

E-mail : katiraju@gmail.com

Tel : +82-42-860-3471 Fax : +82-42-860-3133
}

good balance between wettability and adhesion were observed by the addition of $1.4-8 \mathrm{~mol} \% \mathrm{CuO}$ in $\mathrm{Ag}$ matrix. ${ }^{9)}$ Reliable joining and gas-tightness up to $800^{\circ} \mathrm{C}$ was reported using $\mathrm{Ag}-10 \mathrm{wt} \% \mathrm{CuO}$ braze filler for joining GDC-LSCF ceramics with various metal alloys. ${ }^{7,15}$ The reliability of joints depends not only on the amount of $\mathrm{Cu}$, brazing temperature, and time, but also on the thickness of the braze filler. Moreover, the bonding strength will be improved greatly if the joint is very thin. ${ }^{7,9,14)}$ Nevertheless, realizing a desired thickness is extremely difficult when using conventional powder pressing or paste methods.

Many processes have been developed to prepare thin braze fillers, including screen printing, powder pressing, galvanization, electroplating, and thin foil formulation. ${ }^{12,17-21)}$ Many of these processes require special equipment, which not only adds to the manufacturing cost but also extends the preparation time. Alternatively, researchers have developed a paste formulation to use as a braze filler, which requires organic additives, such as dispersant, binder, and solvent, to adjust the rheology. ${ }^{7,9)}$ As the paste ages, however, its viscosity can change due to volatilization of the solvent, decreasing its flowability. In addition, the braze filler can be squeezed out if the amount of filler paste is high enough, suggesting that the realization of the uniform and thin joints is quite difficult using a paste.

On the other hand, tape casting is a well-known economic and feasible method for shaping thin ceramic tapes with a tailored thickness. ${ }^{22-24)}$ Tape casting is used widely in the processing of multilayered ceramics, electro-ceramics, solidoxide fuel cells, oxygen transport membranes, functionally- 
graded ceramics, structural materials, and many other applications. ${ }^{25-32)}$ Indeed, tape casting of $\mathrm{Ag}$ with a thickness of $64 \pm 1 \mu \mathrm{m}$ has also been reported. ${ }^{33)}$ Tape cast interlayers have also been applied to many types of ceramic-to-ceramic and ceramic-to-metal joints. ${ }^{7,15,18,34,35)}$ Therefore, this study examined the efficacy of tape casting of $\mathrm{Ag}-10 \mathrm{wt} \% \mathrm{CuO}$ braze filler for the joining of GDC-LSM/SUS $460 \mathrm{FC}$ by the $\mathrm{RAB}$ technique. The microstructures of the green tapes, interfacial microstructures and shear strengths of the asbrazed samples were examined.

\section{Experimental Procedure}

To prepare the $\mathrm{Ag}-10 \mathrm{wt} \% \mathrm{CuO}$ paste, 3-roll milling was performed for the Ag paste (S-3902, Innovative Materials \& Devices Inc., South Korea) after adding the appropriate amount of $\mathrm{CuO}$ powder (99.9\%, Kanto Chemical, Japan), ethyl cellulose (Sigma Aldrich, USA) and a-terpineol (Sigma Aldrich, USA) to obtain a homogeneous $\mathrm{Ag}-\mathrm{CuO}$ mixture. To convert this paste to a slurry for tape casting, a binder, plasticizer and solvent were added to the $\mathrm{Ag}-\mathrm{CuO}$ paste followed by ball-milling for $24 \mathrm{~h}$. Polyvinyl butyral (PVB) resin (Butvar B-98, $\mathrm{M}_{\mathrm{w}}=55,000 \mathrm{~g} / \mathrm{mol}$, Solutia, USA) was used as a binder, while a mixture of ethanol (40 wt\%) and toluene (60 wt\%) was used as the solvent. After dissolving $20 \mathrm{wt} \%$ of the binder in a toluene/ethanol mixture, $20 \mathrm{wt} \%$ of dioctyl phthalate with respect to the binder was added as a plasticizer, which imparted flexibility for the tape. Tape casting was performed on the slurry on a moving polyester film using a table top tape caster with a casting rate of $60 \mathrm{~cm} /$ minute. The cast tape was dried in air at room temperature. The resulting green tape thickness was approximately 120 $\mu \mathrm{m}$. Ceramic pellets of $80 \mathrm{vol} \% \mathrm{Ce}_{0.9} \mathrm{Gd}_{0.1} \mathrm{O}_{2-\delta}-20 \mathrm{vol} \%$ $\mathrm{La}_{0.7} \mathrm{Sr}_{0.3} \mathrm{MnO}_{3 \pm \delta}$ (GDC-LSM) were consolidated to $\geq 98 \%$ by sintering at $1400^{\circ} \mathrm{C}$. More details on the fabrication process are reported elsewhere. ${ }^{16)}$ Thermal-resistant SUS 460 FC metal alloy (POSCO, South Korea), $2 \mathrm{~mm}$ in thickness, was chosen as the joining partner for the GDC-LSM ceramic. The SUS 460 FC was newly developed proprietary metal system for high temperature applications.

After cutting the GDC-LSM pellets and SUS 460 FC metal alloys, the surface for joining was polished to a $1 \mu \mathrm{m}$ finish using diamond paste. The samples were cleaned ultrasonically in acetone and dried prior to joining. The filler tape was then inserted between the joining bodies; the same quantity of tape was applied to make a fair comparison. After binder burn-out at $400^{\circ} \mathrm{C}$ for $1 \mathrm{~h}$, the samples were heat-treated in a box furnace at $1050^{\circ} \mathrm{C}$ for $30 \mathrm{~min}$ in air at a heating rate of $5^{\circ} \mathrm{C} / \mathrm{min}$ and then cooled to room temperature. Three types of joint structures were prepared; a whole lap-joint for microstructural and elemental analyses, an offset lap-joint for the shear strength and butt-joint for flexural strength measurements.

The viscosity of the $\mathrm{Ag}-10 \mathrm{wt} \% \mathrm{CuO}$ slurry was measured using a computer-controlled viscometer (LVDV-II+ Pro, Brookfield, USA) at $25^{\circ} \mathrm{C}$. The green microstructures of the tape, joining interfaces and fractured surfaces after bending tests were characterized by scanning electron microscopy (SEM: S-4800, Hitachi). The shear strength of the joints was evaluated at room temperature using a universal testing machine (MTS Landmark, USA) at a head speed of 0.05 $\mathrm{mm} / \mathrm{min}$. For this test, the samples had an offset lap-joined structure based on ASTM D905. ${ }^{36)}$ The shear test was performed on five samples under each condition to ensure the reliability of the joined samples. The flexural strength of joints was measured at RT, 500, 800 and $850^{\circ} \mathrm{C}$ using a three-point bending test. A minimum of three specimens with dimensions of $40 \mathrm{~mm} \times 4 \mathrm{~mm} \times 2.5 \mathrm{~mm}$ (length $\times$ width $x$ thickness) were used for each measurement. The bending test was performed with universal testing machine (UTM) with a constant crosshead speed of $0.5 \mathrm{~mm} / \mathrm{min}$. For a hightemperature measurement, the specimens were dwelled at the testing temperatures in a box furnace for $10 \mathrm{~min}$ to reach thermal equilibrium prior to testing.

\section{Results and Discussion}

Shear thinning behavior and appropriate viscosity are essential for a slurry used for tape casting. A slurry with high viscosity cannot pass the blade, whereas uncontrolled flow and sedimentation occur when the viscosity is too low. For a slurry with an adequate rheology, the viscosity decreases when it passes the blade during the tape casting process due to pseudo-plasticity, and then it recovers after the slurry has left the blade by thixotropy. This shear thinning characteristic can avoid uncontrolled flow or sedimentation. $^{22,23)}$ Fig. 1 shows the viscosity of the $\mathrm{Ag}-10 \mathrm{wt} \% \mathrm{CuO}$ slurry. From the figure, it is evident that the viscosity decreases with increasing shear rate, which presents obvious shear thinning behavior or pseudo-plasticity of the slurry. The viscosity of the slurry was approximately 12 $\mathrm{Pa} \cdot \mathrm{s}$ at a shear rate of $40 \mathrm{~s}^{-1}$, which is satisfactory for tape casting. ${ }^{33)}$

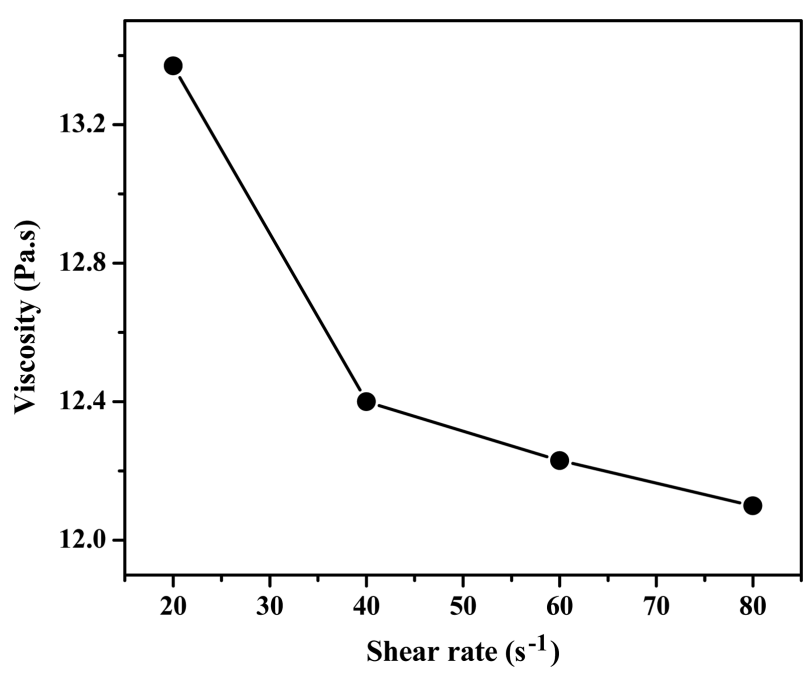

Fig. 1. Viscosity of the $\mathrm{Ag}-10 \mathrm{wt} \% \mathrm{CuO}$ slurry as a function of the shear rate. 

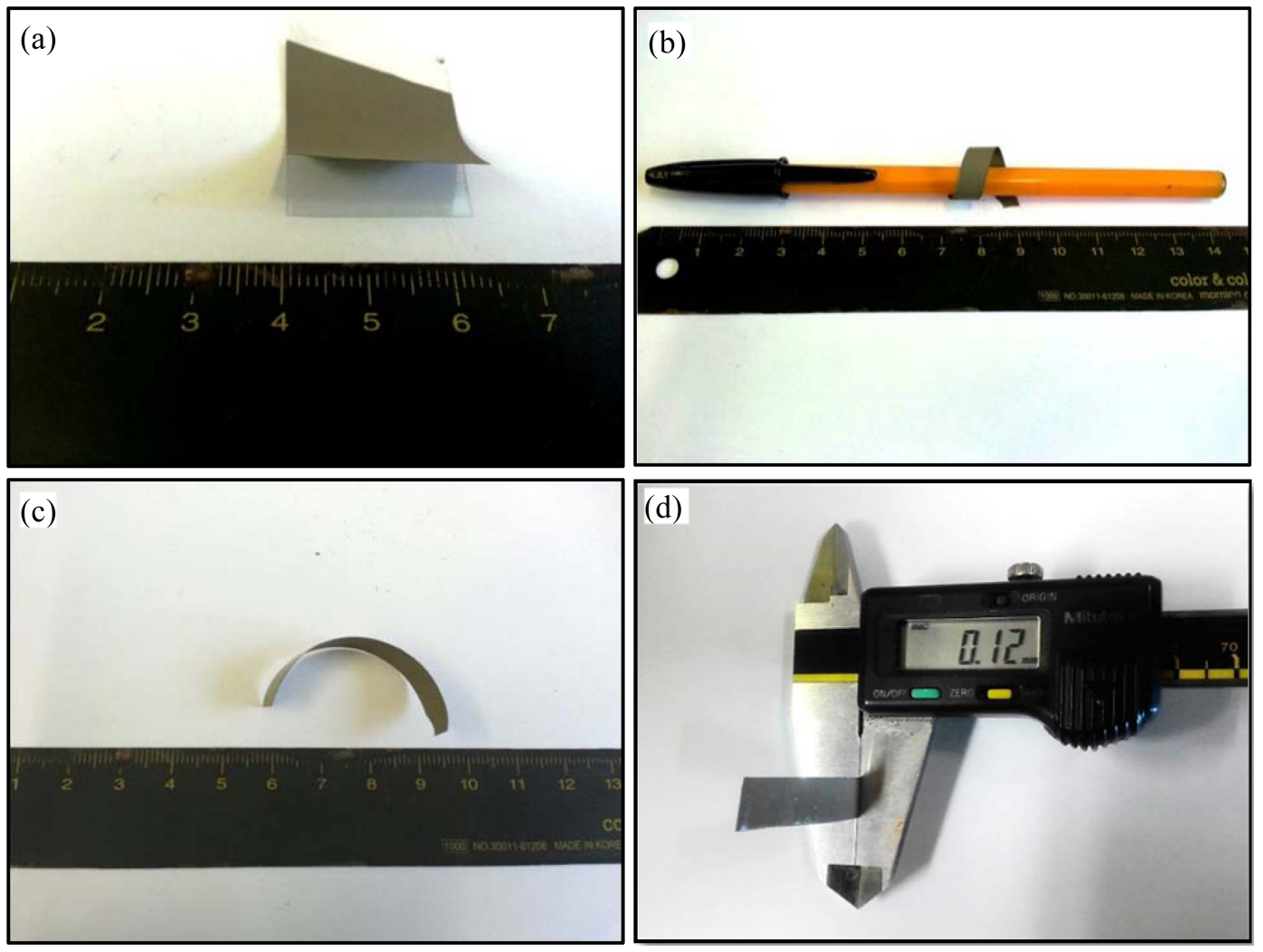

Fig. 2. Digital camera images of $\mathrm{Ag}-10 \mathrm{wt} \% \mathrm{CuO}$ green tape: (a) top-view, (b) wrapped around a pen, (c) side-view bend, and (d) measured thickness $(120 \mu \mathrm{m})$.

Upon drying, the as-prepared green tape was highly flexible with no cracks, as shown in Fig. 2. Fig. 2 (b) shows the flexibility, where the dried cast tape was rolled around a pen without cracking and was unraveled easily without any residual deformation. Based on the flexibility of the tape, its handling should be easy when used as a filler material for brazing. The green tape had a uniform thickness of approximately $120 \mu \mathrm{m}$ (Fig. 2 (d)), which is also beneficial for stacking. Fig. 3 presents the microstructures of the top and bottom surface of the $\mathrm{Ag}-10 \mathrm{wt} \% \mathrm{CuO}$ green tapes. No macro-structural defects, such as bubbles, drapes or cracks, were observed, and the tapes were smooth without significant aggregation. The particle distribution was uniform at both surfaces. The bottom surface (Fig. 3 (b)) of the green tape has higher binder content than the top surface (Fig. 3 (a)) because the solvent volatilizes easily from the top surface compared to the bottom side during drying, which causes higher binder content at the bottom surface. The elemental mapping results revealed (not shown here) a uniform distribution of $\mathrm{Ag}$ and $\mathrm{CuO}$ in the tape. Therefore, tape casting is a convenient and reproducible way to produce a homogeneous, thin, and flexible $\mathrm{Ag}-10 \mathrm{wt} \% \mathrm{CuO}$ tape for
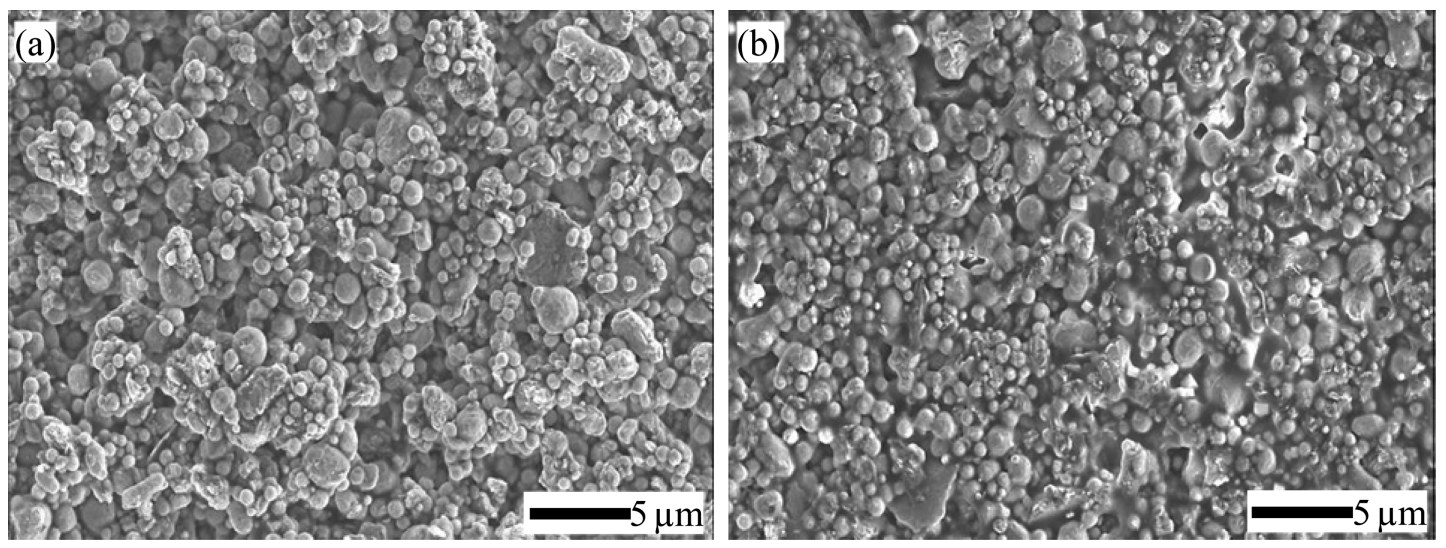

Fig. 3. SEM images of the $\mathrm{Ag}-10 \mathrm{wt} \% \mathrm{CuO}$ green tape: (a) top surface, (b) bottom surface. 

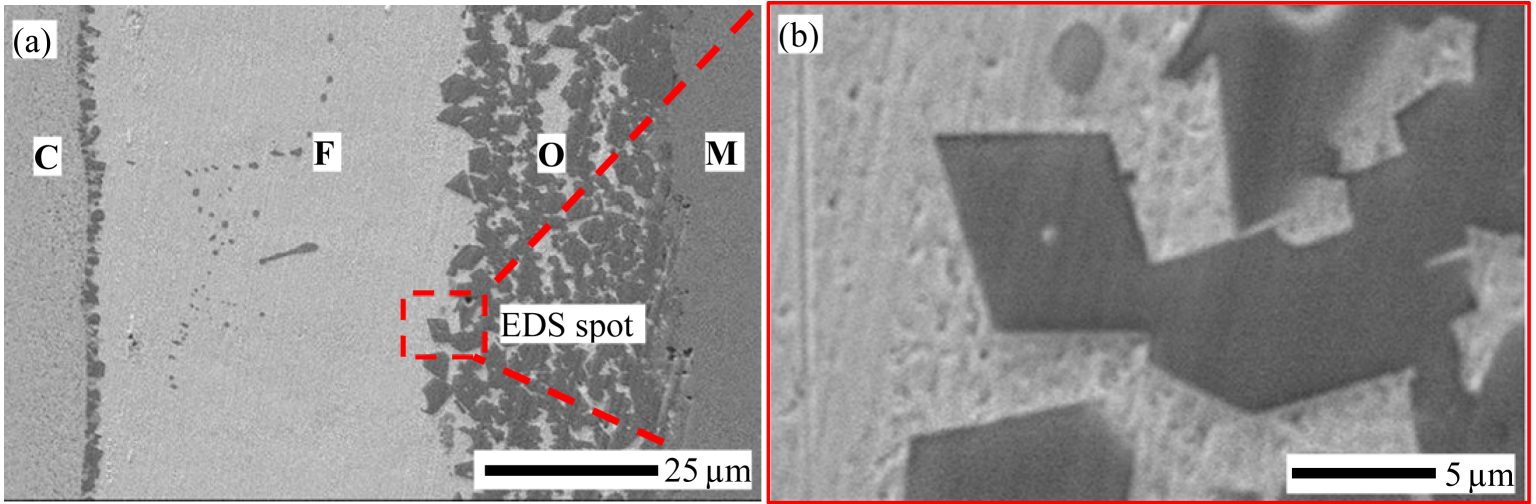

Fig. 4. Microstructure of the GDC-LSM/SUS460 FC brazed at $1050^{\circ} \mathrm{C}$ for 30 minutes in air (C: GDC-LSM, F: Ag-10 wt\% CuO filler, O: oxide layer and M: SUS $460 \mathrm{FC}$ ): (a) SEM image, (b) magnified view of EDS spot.

\section{RAB.}

Figure 4 gives an overview of the cross-sectional SEM image of typical GDC-LSM/SUS 460 FC joint. The braze filler wetted both the ceramic and metal alloy sides well, and the interfaces were sound and crack-free with good physical contact. The observed microstructure was similar to other ceramic-to-metal joints brazed using Ag-10 wt\% $\mathrm{CuO}$ paste. ${ }^{7,16)} \mathrm{CuO}$ did not react with the ceramic part to form an intermediate compound; it tended to precipitate and nucleate at the interface during cooling in the $\mathrm{Ag}$ matrix. ${ }^{15)}$ Four different regions were observed in the SEM images and labeled as $\mathrm{C}$ (ceramic), $\mathrm{F}$ (braze filler), $\mathrm{O}$ (oxidation layer), and $\mathrm{M}$ (metal alloy). The brazed region ( $\mathrm{F}$ and $\mathrm{O}$ ) had a thickness of approximately $75 \mu \mathrm{m}$. The middle area of the brazed region, $\mathrm{F}$, was an Ag-rich region with a small amount of precipitated $\mathrm{CuO}$. The $\mathrm{O}$ (oxide) zone adjacent to the SUS $460 \mathrm{FC}$ at the filler/metal alloy interface has a mean width of approximately $25 \mu \mathrm{m}$, which was formed by the oxidation of various metal elements diffused from alloy. The oxides precipitated in the Ag matrix. According to EDS analysis data for oxide layer (Fig. 4 (b)), shown in Table 1, the oxide layer is composed mainly of $\mathrm{Fe}, \mathrm{Cr}, \mathrm{O}$ and $\mathrm{Cu}$ elements. The composition of the oxide layer consisted of $\mathrm{CuO}$, $\mathrm{Fe}_{x} \mathrm{O}_{y}$, and $\mathrm{Cr}_{x} \mathrm{O}_{y}$. This oxide layer composition is consistent with the literature data of similar SUS metal alloys, ${ }^{7,16)}$
Table 1. EDS Analysis Data of Oxide Layer Region Located in Fig. 4 (a)

\begin{tabular}{ccc}
\hline Element & Weight\% & Atomic\% \\
\hline O K & 225.42 & 63.85 \\
Cr K & 81.28 & 7.08 \\
Fe K & 206.60 & 16.77 \\
Cu K & 130.09 & 9.28 \\
Ag L & 71.78 & 3.02 \\
Total & 715.17 & 100 \\
\hline
\end{tabular}

which revealed the formation of $\mathrm{Cr}_{2} \mathrm{O}_{3}, \mathrm{Fe}_{2} \mathrm{O}_{3}, \mathrm{Fe}_{3} \mathrm{O}_{4}$, and $\mathrm{FeCr}_{2} \mathrm{O}_{4}$ phases by the oxidation of metal alloys in air. Therefore, this oxide layer was formed by the oxidation of $\mathrm{Fe}$ and $\mathrm{Cr}$ that diffused out from SUS $460 \mathrm{FC}$ and the oxidation of $\mathrm{Cu}$ from the braze filler. According to the calculated Gibbs free energy, ${ }^{16)}$ the formation of oxides from the metallic constituents of SUS $460 \mathrm{FC}$ near $1050^{\circ} \mathrm{C}$ is inevitable when $\mathrm{RAB}$ is performed in air.

The mean shear strength of the as-brazed joints was $60 \pm 8$ $\mathrm{MPa}$ at room temperature, which is comparable to other similar ceramic-to-metal joints. ${ }^{7,16}$ Fracturing occurred mainly in the GDC-LSM ceramics or barely at the joining interfaces (cohesive failure) upon the shear strength test.

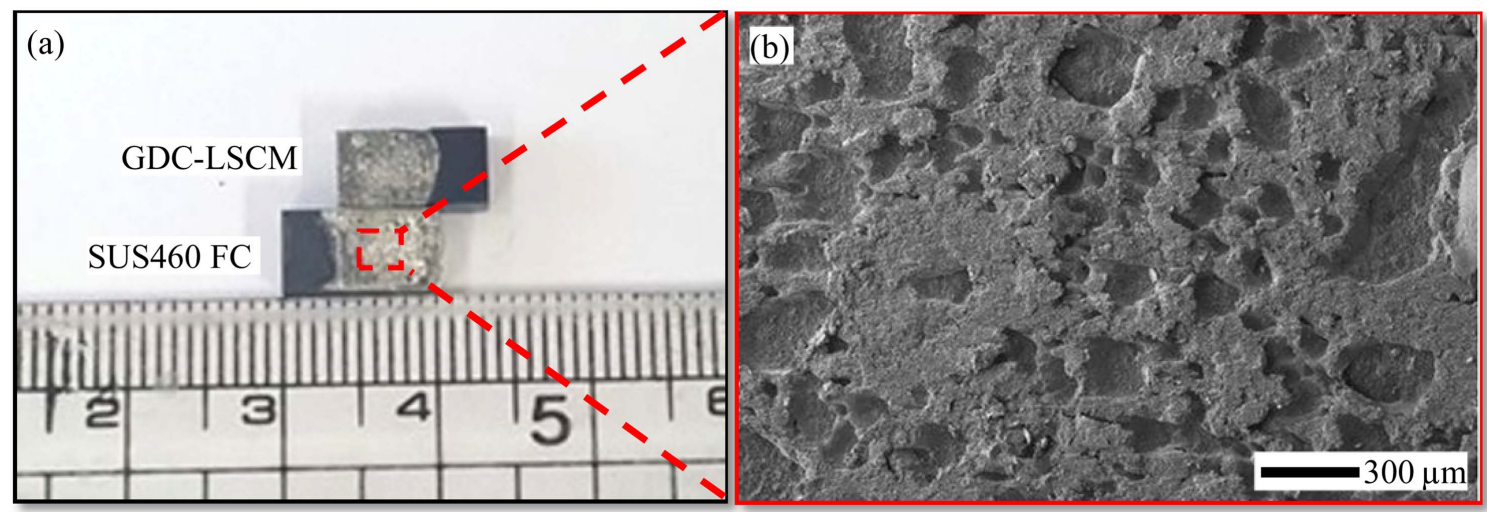

Fig. 5. (a) Digital camera and (b) SEM images of the fractured GDC-LSM/SUS 460 FC as-brazed joint. 


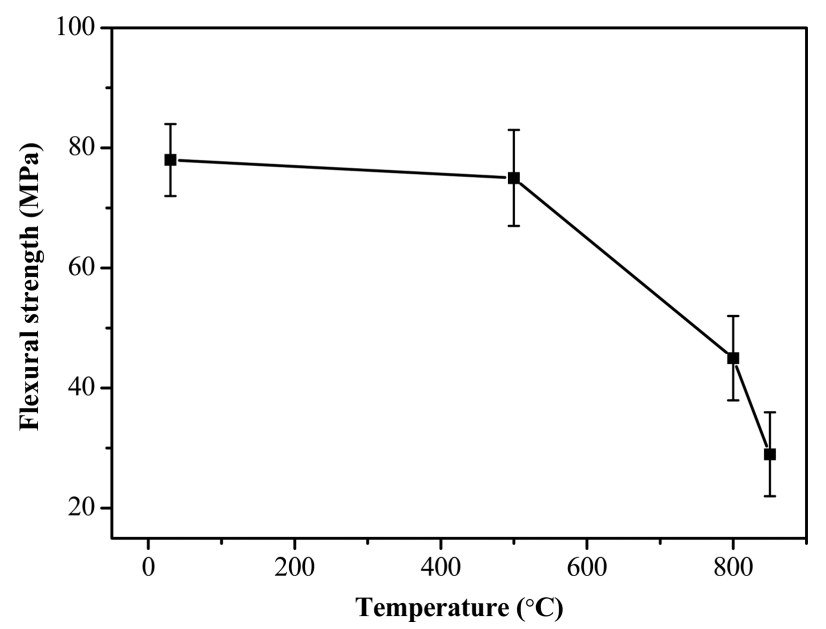

Fig. 6. Flexural strengths of GDC-LSM/SUS $460 \mathrm{FC}$ joints as a function of temperature.

Fig. 5 shows a corresponding fractographic SEM image of a typical joint after cohesive failure. A uniformly distributed and densely packed $\mathrm{Ag}-10 \mathrm{wt} \% \mathrm{CuO}$ braze filler was observed on both surfaces of ceramic and metal alloy. Fracturing at the GDC-LSM ceramics rather than the joining interface indicates that the joining part is mechanically stronger than the GDC-LSM ceramic. Flexural strength data of joints are shown in Fig. 6 as a function of temperatures up to $850^{\circ} \mathrm{C}$. The strengths at RT and $500^{\circ} \mathrm{C}$ of the joints were $78 \pm 6 \mathrm{MPa}$ and $75 \pm 8 \mathrm{MPa}$, respectively. Strength retention at $500^{\circ} \mathrm{C}$ was almost $100 \%$ for the joints. However, the joints showed a clear degradation in strengths at 800 and $850^{\circ} \mathrm{C}$. The strength retentions at 800 and $850^{\circ} \mathrm{C}$ were $57 \%(45 \pm 7 \mathrm{MPa})$ and $37 \%(29 \pm 7 \mathrm{MPa})$ respectively. The strength degradation from $78 \pm 6 \mathrm{MPa}$ at RT to $29 \pm 7 \mathrm{MPa}$ at $850^{\circ} \mathrm{C}$ can be attributed to the softening nature of $\mathrm{Ag}-\mathrm{CuO}$ filler at high temperatures. Overall, the powder or paste form filler can be replaced with a thin tape for reactive air brazing.

\section{Conclusions}

The efficacy of tape casting was examined as a potential replacement for the commonly used $\mathrm{Ag}-\mathrm{CuO}$ powder or paste-form filler for reactive air brazing. The $\mathrm{Ag}-10 \mathrm{wt} \%$ $\mathrm{CuO}$ braze tape filler revealed successful joining properties for the sintered $\mathrm{Ce}_{0.9} \mathrm{Gd}_{0.1} \mathrm{O}_{2-8}-\mathrm{La}_{0.7} \mathrm{Sr}_{0.3} \mathrm{MnO}_{3 \pm \delta}$ (GDC-LSM) and SUS 460 FC metal alloy joint for oxygen transport membrane applications. The as-prepared green tape was quite flexible with no cracks, and could be used in any shape after cutting with easy handling. Green tape with a smoothness and a homogeneous distribution of $\mathrm{Ag}$ and $\mathrm{CuO}$ particles without macro-structural defects was prepared with a thickness of $120 \mu \mathrm{m}$. After heat treatment at $1050^{\circ} \mathrm{C}$ for 30 minutes in air, a reliable and compact GDC-LSM/SUS 460 FC joint was obtained with an average shear strength of $60 \pm 8 \mathrm{MPa}$. High temperature flexural strength of joints revealed strength retention of almost $100 \%$ at $500^{\circ} \mathrm{C}$. How- ever, the strengths were degraded to $57 \%$ and $37 \%$, respectively, at 800 and $850^{\circ} \mathrm{C}$.

\section{Acknowledgments}

This study was conducted under the framework of Research and Development Program of the Korea Institute of Energy Research (KIER) (B6-2456) and (B8-2415).

\section{REFERENCES}

1. J. H. Joo, K. S. Yun, J.-H. Kim, Y. Lee, J. Jung, C.-Y. Yoo, and J. H. Yu, "Substantial Oxygen Flux in Dual-Phase Membrane of Ceria and Pure Electronic Conductor by Tailoring the Surface," ACS Appl. Mater. Interface, 7 [27] 14699-707 (2015).

2. B. T. Na, J. H. Park, J. H. Park, J. H. Yu, and J. H. Joo, "Elucidation of the Oxygen Surface Kinetics in a Coated Dual-Phase Membrane for Enhancing Oxygen Permeation Flux," ACS Appl. Mater. Interface, 9 [23] 19917-24 (2017).

3. J. Sunarso, S. Baumann, J. M. Serra, W. A. Meulenberg, S. Liu, Y. S. Lin, and J. C. Diniz da Costa, "Mixed IonicElectronic Conducting (MIEC) Ceramic-Based Membranes for Oxygen Separation," J. Membr. Sci., 320 [1-2] 13-41 (2008).

4. K. Zhang, J. Sunarso, Z. Shao, W. Zhou, C. Sun, S. Wang, and S. Liu, "Research Progress and Materials Selection Guidelines on Mixed Conducting Perovskite-Type Ceramic Membranes for Oxygen Production," RSC Adv., 1 [9] 1661-76 (2011).

5. K. S. Weil, J. Y. Kim, and J. S. Hardy, "Reactive Air Brazing: A Novel Method of Sealing SOFCs and Other SolidState Electrochemical Devices," Electrochem. Solid-State Lett., 8 [2] A133-36 (2005).

6. S. Baumann, W. A. Meulenberg, and H. P. Buchkremer, "Manufacturing Strategies for Asymmetric Ceramic Membranes for Efficient Separation of Oxygen from Air," J. Eur. Ceram. Soc., 33 [7] 1251-61 (2013).

7. K. Raju, Muksin, S. Kim, K. Song, J. H. Yu, and D.-H. Yoon, "Joining of Metal-Ceramic Using Reactive Air Brazing for Oxygen Transport Membrane Applications," Mater. Des., 109 233-41 (2016).

8. J. Y. Kim, J. S. Hardy, and K. S. Weil, "Dual-Atmosphere Tolerance of Ag-CuO-Based Air Braze," Int. J. Hydrogen Energy, 32 [16] 3655-63 (2007).

9. J. Y. Kim, J. S. Hardy, and K. S. Weil, "Effects of $\mathrm{CuO}$ Content on the Wetting Behavior and Mechanical Properties of a $\mathrm{Ag}-\mathrm{CuO}$ Braze for Ceramic Joining," J. Am. Ceram. Soc., 88 [9] 2521-27 (2005).

10. K. S. Weil, C. A. Coyle, J. T. Darsell, G. G. Xia, and J. S. Hardy, "Effects of Thermal Cycling and Thermal Aging on the Hermeticity and Strength of Silver-Copper Oxide AirBrazed Seals," J. Power Sources, 152 97-104 (2005).

11. J. S. Hardy, J. Y. Kim, and K. S. Weil, "Joining Mixed Conducting Oxides Using an Air-Fired Electrically Conductive Braze," J. Electrochem. Soc., 151 [8] J43-9 (2004).

12. V. V. Joshi, A. Meier, J. Darsell, K. S. Weil, and M. Bowden, "Trends in Wetting Behavior for $\mathrm{Ag}-\mathrm{CuO}$ Braze Alloys on $\mathrm{Ba}_{0.5} \mathrm{Sr}_{0.5} \mathrm{Co}_{0.8} \mathrm{Fe}_{0.2} \mathrm{O}_{(3-6)}$ at Elevated Temperatures in Air," 
J. Mater. Sci., 48 [20] 7153-61 (2013).

13. H. Chen, L. Li, R. Kemps, B. Michielsen, M. Jacobs, F. Snijkers, and V. Middelkoop, "Reactive Air Brazing for Sealing Mixed Ionic Electronic Conducting Hollow Fibre Membranes," Acta Mater., 88 74-82 (2015).

14. J. Y. Kim and K. S. Weil, "Effects of Brazing Time and Temperature on the Microstructure and Mechanical Properties of Aluminum Air Brazed Joints," J. Am. Ceram. Soc., 90 [12] 3830-37 (2007).

15. K. Raju, Muksin, and D. H. Yoon, "Reactive Air Brazing of GDC-LSCF Ceramics Using Ag-10 wt\% CuO Paste for Oxygen Transport Membrane Applications," Ceram. Int., 42 [14] 16392-95 (2016).

16. M. F. R. Wahid, D.-H. Yoon, K. Raju, S. Kim, K. Song, and J. H. Yu, "Interfacial Microstructure and Shear Strength of Reactive Air Brazed Oxygen Transport Membrane Ceramic-Metal Alloy Joints," Met. Mater. Int., 24 [1] 15769 (2018)

17. K. M. Erskine, A. M. Meier, and S. M. Pilgrim, "Brazing Perovskite Ceramics with Silver/Copper Oxide Braze Alloys," J. Mater. Sci., 37 [8] 1705-9 (2002).

18. A. Kaletsch, E. M. Pfaff, and C. Broeckmann, "Effect of Aging on Microstructure and Mechanical Strength of Reactive Air Brazed BSCF/AISI 314-Joints," Adv. Eng. Mater., 16 [12] 1430-36 (2014).

19. K. Bobzin, M. Ote, S. Wiesner, A. Kaletsch, and C. Broeckmann, "Characterization of Reactive Air Brazed Ceramic/Metal Joints with Unadapted Thermal Expansion Behavior," Adv. Eng. Mater., 16 [12] 1490-97 (2014).

20. B. Kuhna, F. J. Wetzel, J. Malzbender, R. W. Steinbrech, and L. Singheiser, "Mechanical Performance of ReactiveAir-Brazed (RAB) Ceramic/Metal Joints for Solid Oxide Fuel Cells at Ambient Temperature," J. Power Sources, 193 199-202 (2009).

21. R. Kiebach, K. Engelbrecht, K. Kwok, S. Molin, M. Sogaard, P. Niehoff, F. Schulze-Küppers, R. Kriegel, J. Kluge, and P. V. Hendriksen, "Joining of Ceramic $\mathrm{Ba}_{0.5} \mathrm{Sr}_{0.5} \mathrm{Co}_{0.8} \mathrm{Fe}_{0.2} \mathrm{O}_{3}$ Membranes for Oxygen Production to High Temperature Alloys," J. Membr. Sci., 506 11-21 (2016).

22. D. Hotza and P. Greil, "Review: Aqueous Tape Casting of Ceramic Powders," Mater. Sci. Eng. A, 202 [1-2] 206-17 (1995).

23. M. Jabbari, R. Bulatova, A. I. Y. Tok, C. R. H. Bahl, E. Mitsoulis, and J. H. Hattel, "Ceramic Tape Casting: A Review of Current Methods and Trends with Emphasis on Rheological Behaviour and Flow Analysis," Mater. Sci. Eng. B, 212 39-61 (2016).

24. R. K. Nishihora, P. L. Rachadel, M. G. N. Quadri, and D.
Hotza, "Manufacturing Porous Ceramic Materials by Tape Casting - A Review," J. Eur. Ceram. Soc., 38 [4] 9881001 (2018).

25. Z. He, K. B. Andersen, F. B. Nygaard, and K. K. Hansen, "A Combined SEM, CV and EIS Study of Multi-Layered Porous Ceramic Reactors for Flue Gas Purification," Ceram. Int., 39 [1] 847-51 (2013).

26. S. S. Kim, J. K. Chung, I. S. Kim, J. S. Song, C. J. Kim, and W. J. Kim, "Dielectric Properties of Ferroelectric $\left(\mathrm{Ba}_{0.6} \mathrm{Sr}_{0.4}\right) \mathrm{TiO}_{3}$ Thick Films Prepared by Tape-Casting," J. Electroceram., 17 [2-4] 451-54 (2006).

27. D. Stover, H. P. Buchkremer, and S. Uhlenbruck, "Processing and Properties of the Ceramic Conductive Multilayer Device Solid Oxide Fuel Cell (SOFC)," Ceram. Int., 30 [7] 1107-13 (2004).

28. J. M. Serra, J. Garcia-Fayos, S. Baumann, F. SchulzeKüppers, and W. A. Meulenberg, "Oxygen Permeation through Tape-Cast Asymmetric All-La ${ }_{0.6} \mathrm{Sr}_{0.4} \mathrm{Co}_{0.2} \mathrm{Fe}_{0.8} \mathrm{O}_{3-8}$ Membranes," J. Membr. Sci., 447 297-305 (2013).

29. N. C. Acikbas, E. Suvaci, and H. Mandal, "Fabrication of Functionally Graded SiAlON Ceramics by Tape Casting," J. Am. Ceram. Soc., 89 [10] 3255-57 (2006).

30. K. Lindqvist and E. Liden, "Preparation of Alumina Membranes by Tape Casting and Dip Coating," J. Eur. Ceram. Soc., 17 [2-3] 359-66 (1997).

31. J. S. Park, H. J. Lee, S. S. Ryu, S. M. Lee, H. J. Hwang, and Y. S. Han, "Optimization of Burnout for Reaction Bonded $\mathrm{Si}_{3} \mathrm{~N}_{4}$ Substrate Fabrication by Tape Casting Method," J. Korean Ceram. Soc., 52 [6] 435-40 (2015).

32. J. S. Park, S. M. Lee, Y. S. Han, H. J. Hwang, and S. S. Ryu, "Effects of Debinding Atmosphere on Properties of Sintered Reaction-Bonded $\mathrm{Si}_{3} \mathrm{~N}_{4}$ Prepared by Tape Casting Method," J. Korean Ceram. Soc., 53 [6] 622-27 (2016).

33. N. Straue, M. Rauscher, M. Dressler, and A. Roosen, "Tape Casting of ITO Green Tapes for Flexible Electroluminescent Lamps," J. Am. Ceram. Soc., 95 [2] 684-89 (2012).

34. H. Liang, K. Zuo, Y. Xia, D. Yao, J. Yin, and Y. Zeng, "Joining of Dense $\mathrm{Si}_{3} \mathrm{~N}_{4}$ Ceramics with Tape Cast Lu-AlSi-O-N Interlayer," Ceram. Int., 44 [5] 4824-28 (2018).

35. T. Okuni, Y. Miyamoto, H. Abe, and M. Naito, "Joining of AlN and Graphite Disks Using Interlayer Tapes by Spark Plasma Sintering," Mater. Des., 54 755-59 (2014).

36. S. Kim, J. H. Joo, S.-D. Kim, and S.-K. Woo, "Evaluation of $\mathrm{CaO}-\mathrm{Al}_{2} \mathrm{O}_{3}$ Adhesive Bonding Properties for $\beta^{\prime \prime}-\mathrm{Al}_{2} \mathrm{O}_{3}$ Solid Electrolyte Sealing for Alkali Metal Thermal Electric Converter," Ceram. Int., 39 [8] 9223-27 (2013). 